\title{
The Link Between Operations Strategy and Human Resource Management for NGOs Working in Unstable Environments
}

\author{
Ahmed Hassin \\ Australian Red Cross Blood Service, Australia
}

\begin{abstract}
This article discusses the link between operations strategy and strategic human resources management for non-government organisations. Human resources are a great asset for NGO to plan and implement their operations strategies. The article shows how HRM should be proactive and responsive to any changes in the operational environment. Strategic human resource management could lead to organisation's competitive advantage. It also enables more effective stakeholder interaction and leads to better efficiencies in implementation of operations strategy. Strategic HRM can create multi-skilled staff, who can easily be tuned to implement various activities. IT and HR are intrinsically linked in execution of operations strategy. The example given from Iraq about NGO staff operating in unstable context shows how HRM should be proactive and responsive to meet operations targets.
\end{abstract}

\section{Keywords}

Operations strategy, NGO, human resources

\section{Introduction}

The growing pressure to become efficient, effective and competitive players has led many nongovernment organisations (NGO) to implement a variety of techniques, operate according to a variety of philosophies and utilise a variety of approaches. As a very valuable and most effective part of service organisations (like NGOs), human resources play a key role in the success or failure of delivery of services. Effective human resource management (HRM) helps the organisation's operations strategy to be implemented effectively and help the organisation to gain competitive advantage.

Being under service organisation category, non-profit organisations are a clear example of how people management in the operations strategy can lead to gain competitive advantage. As one of the operations resource, IT is considered an important partner to HRM in implementing the operations strategy. Hill's influential methodology for market order-winners and qualifiers is very important to consider before moving on to a discussion of operational processes and infrastructure (Hill, 2000). People management can be considered as an important order winner/qualifier for non-profit organisations as many services are more labour intensive than manufacturing. In many cases, "hightouch" cannot be replaced by "high-tech" as in manufacturing, which makes managing people more

Copyright (C) 2009 Victoria University. This document has been published as part of the Journal of Business Systems, Governance and Ethics in both online and print formats. Educational and non-profit institutions are granted a nonexclusive licence to utilise this document in whole or in part for personal or classroom use without fee, provided that correct attribution and citation are made and this copyright statement is reproduced. Any other usage is prohibited without the express permission of the publisher. prominent in the service sector than in manufacturing (Prajogo, 2006). Koys (2000) argues that there is a lot of evidence and studies which "indicate that there are numerous people management activities that can be used to support business strategies". In this study, I have discussed non-profit organisation operating in unstable operations environment. Iraq is an example, where the operational context for 
humanitarian organisation is very difficult. I have tried to examine the impact of people management on implementing operations strategy and how human resources are customised to meet operation strategy to gain competitive advantage and sustainability.

\section{Theoretical Background and Literature Review}

Operations Management is management of a systemic transformation process to convert a set of inputs (labour, equipment, raw material, information and other capital resources) into outputs (Bayraktar et al, 2007). If operations are to play a serious role in helping organisations to stay "ahead of the game" it is important that strategic operations concepts are aligned with those, like competence, that are central to mainstream strategic management (Lewis, 2003). Strategies are created to raise funds for nongovernment organisations (NGO), improve operations and service for beneficiaries, etc. But no matter the strategy and its objective more often than not it fails to deliver the results (Speculand, 2007). An organisation's ability to seek and maintain a competitive advantage rests on its ability to acquire and deploy resources that are coherent with the organisation's competitive needs (Kathuria et al, 2007). The operations management abilities provide vital foundations, and operations strategy can play a role in developing these capabilities (Brown et al, 2003). One of the key resources is people. The link between operations strategy and people management is important as senior-level management personnel will be involved in determining the skill requirements of the operations (Brown et al, 2003).

Employees are often described as the organisation's "greatest asset" and are characterised as just another factor in production, to be managed efficiently. In order to do this, organisations need to adopt a more strategic orientation and have the resources to enable employees to have a greater involvement with broader organisational strategies (Tansley et al, 2001). HRM has important role and basic functions that managers do: Planning, Organising, Staffing, Leading and controlling. HRM should be able to link HR to the rest of the organisation through HR policies for each HR activity designed to support achieving organisational objectives (Dessler\& Lloyd-Walker, 2007). "The HR system represents the approach to improve and exploit the intellectual capital in the firm" (Juhl et al, 2000). Christie (2007) argues that "HR function needs to have tactical expertise in six areas: forecasting and staffing, staff development, performance management, rewards and recognition, employee relations and Communication". It is proposed that effective HRM practice enables the utilisation of the workforce as a source of competitive advantage. Organisations following a focus strategy will require an accumulation HRM philosophy. HR also enables the executive team to analyse organisational preparedness, efficiency and adaptability to change. It, explicitly, links and aligns all HR structures, programs, priorities and objectives to the organisation overall strategy (Christie, 2007). Onyango et al (2009) argue that "functionally flexible human resource systems in conjunction with differentiation strategies are associated with high organizational performance, whereas numerically flexible human resource systems and cost reduction strategies are linked with low organizational performance". Othman (1996) finds that this is because organisations pursuing this strategy need adaptable employees to enable them to serve very specific needs of their customers. These organisations emphasise innovation to differentiate themselves from competitors. Employees need to be able to work collaboratively for healthy operational environment. An examination of strategic integration could only be carried out by examining HRM involvement in strategic planning and HRM practice for each strategy (Othman, 1996).

Human Resource executives say that people management has to be more coordinated with business strategy; and, as Koys (2000) found that "anecdotal evidence shows that big international organisations formally design their human resource strategies to help implement business strategy". NGOs should adopt a good workforce planning model to guarantee its healthy operational HRM. Strategic resource combinations had to be considered with other, often non-strategic, resources, and particularly noticeable with strategic human resources (Lewis, 2003). People is the resource that underlies many of the other elements of business strategy statements. HR managers can use the people- related elements of business strategy statements as goals when developing their own strategy statements (Koys, 2000). Adoption of Brockbank's (1999) HR competitive advantage index provides a useful logic for assessing the extent to which HR creates true competitive advantage. Borckbank's model is composed of four quadrants: Operationally Reactive HR, which focuses on implementing the 
basics (daily demands). The second quadrant is Operationally Proactive HR which improves the design and delivery of the HR basics. Third one is Strategically Reactive HR which focuses on implementing the business strategy, and the fourth quadrant is Strategically Proactive HR which focuses on creating future strategic alternatives (Bronckbank, 1999).

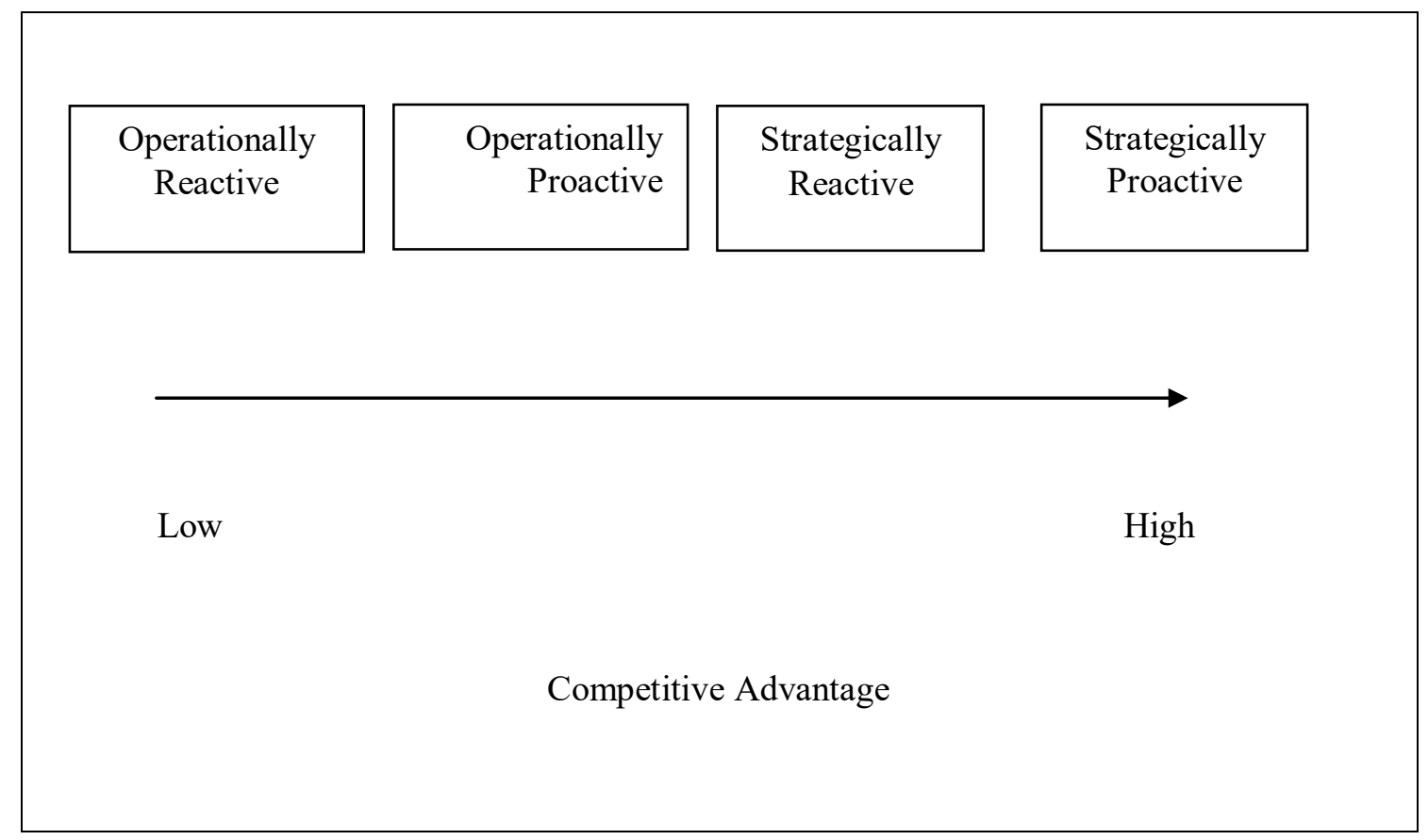

Figure 1: Brockbank's (1999) HR competitive advantage index

There are many reasons why NGOs should pay more attention to the importance to human resource management to achieve the strategy goals. It is important that their staff members are treated fairly, keep them motivated, and they should seek to improve the performance of fieldworkers (Ahmad, 2002). Evidence from examining one of the biggest NGOs in South Africa has shown that the organisation has focused predominantly on meeting the demands of its donors, and subsequently has had limited capacity to meet its growing needs in regard to human resources and organisational development (Arend, 2008).

These external pressures have included the need to reduce costs, increase flexibility, raise quality, lessen variability and shorten lead times. Many organisations have reacted to these drivers by implementing tools and techniques that allow them to introduce "leanness and leaner methods of working" (Radnor et al, 2004). "Leanness" is the term that can be used to describe "doing more with less" i.e. improved utilisation of the organisation's resources. The contextual factors surrounding leanness are to be considered, and argue that it can be shown to be an evolutionary process requiring adaptation within a particular context, rather than a state than can be universally defined (Radnor et al, 2004). In order to respond to environmental changes and better fulfil stakeholder expectations, organisations need to enhance their internal integration by restructuring to cross-functional teams, blurring the task definition of classical functional departments. Adoption of a cross-functional structure along with the emergence of process-oriented organisations (like NGOs) attempts to reduce the gaps among the functions of an organisation (Bayraktar et al, 2007). For NGO to be strategically proactive, literature suggests that developing a flexible and multi-skilled workforce, creating a culture that allows initiative, will enhance creativity and supportiveness to thrive throughout the organisation (Brown\& Bessant, 2003). This idea could be used to suggest that the effective organisation should be able to modify its resources as the circumstances change (Radnor et al, 2004). This can lead to flexible operation processes, achieve objectives and attract donor funds.

The multi-skilled teams should be equipped with IT solutions to achieve the operation strategy objectives. IT is a stimulus to effecting transformational change (Tansley et al, 2001). The attainment of competitive advantage requires the interaction of IS with the structure, HR management, 
technology and transportation systems (Prasad et al, 2003). It is important to see an integrated framework for aligning information technology applications across various functional areas with operations strategy (Kathuria et al, 2007). For the efficient use and utility of the operation management system it is important to take into account how the users relate to the real life use of the information system. Customer (beneficiary and donor) satisfaction with the system may directly reflect organisational efficiency (Lemmetty \& Häyrinen, 2005). The level of organisation performance is conditional upon the joint effect of the quality of the human resource system and the operational system (Juhl et al, 2000).

Operations strategy requires HR staff to have excellent conceptual and systemic thinking skills and good understanding of the social, political and financial context in which the organisation operates (Christie, 2007). It is suggested that what is also required is an increased involvement of line managers in HR administration, operations and strategy (Tansley et al, 2001). Middle managers are concerned with the operational aspects of implementing strategy, which is often decided without their input, but they grasp the reasoning that affects strategic decision making. This responsibility brings with it a considerable interpretative role which is influenced by the self-perceived role of middle managers - to make actionable strategies and plans made at higher levels (Holden et al, 2004). "Giving those strategies to line managers and other executives will help those other managers see the valuable contribution made by the HR function" (Koys, 2000). Under HRM, line managers are centrally responsible for devising and driving an integrated business management and people management strategy. Thus, the middle manager is seen to be an interpreter and an implementer of strategy (Stewart et al., 1994).

\section{NGO Operations in Unstable Developing Countries}

NGOs working in unstable developing countries are doing their best for sustainability of their financial, technical, and human resources to be responsive to humanitarian needs. In unstable operational environment, it is necessary to retain critical staff. Ramlall (2004) finds turnover of key employees is a serious threat of the existence and sustainability of the operations in such contexts. There is a significant economic impact on organisations losing one of its critical staff, especially given the knowledge that is lost with his/her departure (Ramlall, 2004). One of the solutions to retain critical staff, NGO can follow the Quinn and Shepard 12-item satisfaction scale to measure job satisfaction. This scale consists of five measures: satisfaction with pay, promotion, supervision, work and coworkers (Clugston, 2000). Ahmad (2002) points out that experience from Bangladesh has shown that poor treatment of local NGO field workers could lead to difficulties in retaining skilled people, and, consequently, affecting the operations. It is true, he argues, that donors want their money to be used efficiently and to reach the target beneficiaries; however, it is more difficult to recruit, develop and retain good staff in any low status. It should be noted that the goal of empowering beneficiaries can not be achieved "if the change agents are themselves powerless" (Ahmad, 2002). Operating within such a restrictive donor structure, NGOs that try to contribute to sustainable development are unable to sustain themselves (O'Grady, 2004).

After the 2003 bombing of the UN and ICRC headquarters in Baghdad, majority of international agencies left Iraq. Those organisations had been forced to manage their staff from alternative bases in Iraq's neighbouring countries (NCCI, 2006). According to observations of International Crisis Group (2007), between 2005 and 2007, Iraq was on the edge of slipping into a civil war.

From the context mentioned above, the problem of operations and delivery is a real concerns for all Iraqi and international organisations managing staff from across the borders. In a study released by the NGO Coordination Committee in Iraq (NCCI) in August 2006 the following challenges were identified: Communication, Assessment, monitoring, evaluation, donors' perception, Personnel Management, and Finance, administration and logistics (NCCI, 2006). The main reason behind gaps is the instability of the Iraqi daily life and lack of security which is an obstacle in managing and developing HR. Consequences like: remote management, turn over, skill and competency quality, communication problems, shortage of HR expertise and HR systems (NCCI, 2006) had hindered organisations' performances. Remote management of staff has, sometimes, negative effects on the staff and, consequently, the project activities and objectives. 
Tele-working was one of the methods adopted by many organisations to overcome operational problems. Tele-working is a way of flexible working that enables workers to get access to their activities from different locations by the use of Information and Communication Technologies. An organisation may adopt one or several types of tele-working: home-based tele-working, tele-centres, and mobile tele-working. Tele-working has been proposed as a cure for a variety of organisational and social ills (Pérez et al, 2004). Flexibility proposed by tele-working implemented by organisations helped their personnel to have the work-life balance, adapt their working conditions, give some autonomy in to implement the operations strategy and save time and resources. This idea could be used to suggest that the effective organisation should be able to modify its resources as the circumstances change (Radnor et al, 2004) and this can lead to flexible operations processes, achieve objectives and attract donor's funds.

However, setting up operations in some developing countries has a burden of low level of industrialisation and the lack of basic services, including Information and Communication Technology (ICT) (Prasad et al, 2003). Since the invasion of the US-led forces in 2003, the infrastructure in Iraq has been damaged badly. Despite the billions of dollars spent by the US and Iraqi governments on rehabilitation since 2003 (The Globalist, 2005), Iraq is still struggling to achieve adequate reconstruction of basic services, and securing and applying the investment required (IFRC, 2009: 3).For reliable information systems, it is important that telecommunication infrastructure be robust (Prasad et al, 2003).

Inter-organisational relations, within a humanitarian aid relief and recovery context, may be characterised by the exchange of information, staff, goods, cash and other items. "The success of humanitarian aid operations ultimately depends on the ability of organisations to work together" and how their staff are flexible enough to adapt to any changes (Moore et al, 2003). It is vital that employees have the necessary technical and problem-solving skills for a quality strategy when the focus is on continuous improvement of operations to increase customer and donor satisfaction (Juhl et al, 2000). Therefore, the operational focus will need comprehensive quality training at tool and technique level in support of an overall framework such as business excellence model (Leonard et al, 2002). The degree of capability, adaptability and flexibility can be generated by developing and sustaining employee learning and skill growth (Smith 2004). People development can be considered as an important donor-attraction factor for non-profit organisations as they are more labour intensive. "Organisations of whatever persuasion- for-profit, not-for-profit and public service- must pursue the twin and related goals of improved efficiency and productivity" (Sheedy, 2008).

Remote management of operations staff has, sometimes, negative impacts on the staff and, consequently, the project activities and objectives. Weak team spirit and poor communications among the staff and their management are some of them. Levy (2001) has highlighted that it should be noted that senior management in organisations should not isolate itself from teams working on the ground. He argues that there could be various reasons why management may, sometimes, not pay attention for operational staff: efficiency of teams and good achievements, distance between operations field and management base (remote management) or even a great extent of autonomy given by the organisation. Such complacency in management approach will have negative impact on operations. By time, this may very likely create a "Nut Island Effect" on teams. The Nut Island effect is a "destructive organizational dynamic that pits a homogenous, deeply committed team against its disengaged senior managers" (Levy, 2001).

In order to get operations strategies implemented effectively in Iraq, NCCI (2006) suggested some solutions for remote management of staff, which vary depending on the context. The following techniques can be used to fill in gaps:

- ICT means: emails, chat, video chatting, and satellite phones. ICT equipment will enable better communications among staff themselves and between staff and the HR manager. IT can help in lowering administrative costs, increase productivity, speed response times, improve decision making, and enhance internal and external stakeholders and beneficiaries (Shrivastava and Shaw, 2003). 
- Utilising the suggested "NCCI Human Resource (HR) database" and "Local Network". Both alternatives use standardised formats including informal networks (NCCI, 2006). Line manager should consider more time for induction and try to provide more support and coaching during that period. Training is to be planned according to staff skills and needs.

- Delegation of authorities and responsibilities to staff existing inside Iraq against clear policies.

- Qualified leader inside Iraq that can influence and motivate employees who should be a powerful focal point and communicator between senior management outside Iraq and rest of management and staff inside Iraq.

- Clear and constant communications between management outside and inside Iraq.

\section{Conclusion}

Personnel are looked at as one of the important strategic resources for originations, especially nonprofits. Human resources set and implement operation strategies. Multi-skilled human resources can be an order winner/qualifier for organisations. The continuous development of staff with quality training, equipping them with ICT solutions and direct involvement will help organisations in implementing operations strategies effectively. HRM strategies and operations strategies should be interlinked to each other to gain competitive advantage. IT is an important component of operations process which enables human resources implementing strategies efficiently.

\section{References}

Ahmad, M 2002, 'Who cares? The personal and professional problems of NGO fieldworkers in Bangladesh', Development in Practice, May 2002, Vol. 12, No 2.

Arend, E 2008, 'Wellness programme and health policy development at a large faith-based organisation in Khayelitsha South Africa', African Journal of AIDS Research 2008, vol. 7, no 3 , pp. 259-270

Bayraktar E, Jothishankar M.C., Tatoglu E. and Wu T., 2007, 'Evolution of operations management: past, present and future', Management Research News, Vol. 30 No. 11, pp. 843-871

Bronckbank, W. 1999, "If HR were really strategically proactive: present and future directions in HR's contribution to competitive advantage", Human Resource Management, vol. 38, No. 4, Pp. 337-352.

Brown S. and Bessant J., 2003, 'The manufacturing strategy-capabilities links in mass customisation and agile', International Journal of Operations \& Production Management, Vol. 23 No. 7, pp. 707-730

Clugston, M., 2000, "The mediating effects of multidimensional commitment on job satisfaction and intent to leave", Journal of Organizational Behaviour 21, Pp. 477-486.

Christie, S 2007, 'Workforce Capacity-Building', Policy \& Practice March 2007, http://web.ebscohost.com.ezproxy-f.deakin.edu.au/ehost/pdf?vid=9\&hid=103\&sid=07314ba0976c-48da-b815-17541390179c\%40sessionmgr 14

Hill T., 2000, Manufacturing Strategy Text and Cases, $2^{\text {nd }}$ edition

Holden L. and Roberts I., 2004, 'The depowerment of European middle managers Challenges and uncertainties', Journal of Managerial Psychology, Vol. 19 No. 3, pp. 269-287

International Federation of the Red Cross and Red Crescent Societies (IFRC) 2009, Plan 2009-2010 Iraq, viewed 22/9/2009 < http://www.iraqslogger.com/downloads/ICRCIraq2009 10.pdf $>$

International Crisis Group (ICG) 2009, Iraq's Provincial Elections: The Stakes, Middle East Report $N^{\circ} 82$, 27 January 2009, viewed 1/10/2009 $<$ http://www.crisisgroup.org/home/index.cfm? id $=5883 \& \mathrm{l}=1>$,

JUHL, H. J, KRISTENSEN, K, KANJI, G. K. \& T. W. BATLEY 2000, 'Quality management: a comparison of cultural differences', Total Quality Management, Vol. 11, No. 1, 2000, 57-65

Kathuria R., Joshi M. P. and Porth S. J., 2007, 'Organizational alignment and performance: past, present and future', Management Decision, Vol. 45 No. 3, pp. 503-517

Koys, D 2000, 'Describing the Elements of Business and Human Resource Strategy Statements', Journal of Business and Psychology, Vol. 15, No. 2, Winter 2000, pp 265-276 
Lemmetty, K \& Häyrinen, E 2005, Operation Management System Evaluation in the Central Finland Health Care District - End Users' View of System Implementation, EFMI - European Federation for Medical Informatics, pp 605-609

Leonard D. and McAdam R. 2002, 'The strategic impact and application of the business excellence model: implications for quality training and development', Journal of European Industrial Training, vol. 26, No. 1 Pp 4-13

Lewis M. A., 2003, 'Analysing organizational competence: implications for the management of operations', International Journal of Operations \& Production Management, Vol. 23 No. 7, pp. $731-756$

Levy, P 2001, 'The Nut Island Effect', Harvard Business Review, March 2001, pp 51-59

Moore, S, Eng, E \& Daniel, M 2003, 'International NGOs and the Role of Network Centrality in Humanitarian Aid Operations: A Case Study of Coordination During the 2000 Mozambique Floods', Disasters, 2003, 27(4): 305-318

NCCI 2006, Distance Challenges Faced by NGOs in Iraq, Interviews and workshop report, August 2006.

O'Grady, M. 2004, Managing HIV/AIDS in the Workplace: Examples of Nine Non-Governmental Organisations in South Africa, Zambia and Zimbabwe (commissioned by Novib and Oxfam International, November 2004). Oxfam International.

Onyango, E, Monica, A, Edwin, O \& Roselyne, O, 2009, 'The Role of Human Resource Systems and Competitive Strategies in Hospitality Organizational Performance in Kenya', International Journal of Hospitality \& Tourism Administration; 2009, Vol. 10. No 2, p174-194

Othman R. B., 1996, 'Strategic HRM: evidence from the Irish food industry', Personnel Review, Vol. 25 No. 1, pp. 40-58.

Pérez M., Sa'nchez A.M, Carnicer M.P.L and Vela Jime'nez M.J, 2004, The environmental impacts of teleworking A model of urban analysis and a case study.

Prajogo D. 2006, 'The implementation of operations management techniques in service organisations, An Australian perspective', International Journal of Operations \& Production Management, Vol. 26 No. 12, pp. 1374-1390

Prasad S. and Sounderpandian J. 2003, 'Factors influencing global supply chain efficiency: implications for information systems', Supply Chain Management: An International Journal, vol. 8, No.3, pp.241-250.

Ramlall, S. 2004, 'A Review of Employee motivation Theories and their Implications for Employee Retention within Organizations", The Journal of American Academy of Business, Cambridge

Radnor, Z \& Boaden R. 2004, 'Developing an understanding of corporate anorexia', International Journal of Operations \& Production Management, Vol. 24 No. 4, pp. 424-440

Sheedy, C 2008, 'Lessons in efficiency and productivity', Management Today: 2008, June, pp 12-19

Smith, I. 2004, 'Continuing professional development and workplace learning 7: human resource development- a tool for achieving organisational change', Library Management, Vol. 25, No.3, Pp. 148-151

Speculand R. 2007, 'One million pound investment and 90 percent chance of failure - would you sign off?' STRATEGIC DIRECTION, Vol. 23, No. 2, pp. 3-5

Tansley C., Newell C.\& Williams H. 2001, 'Effecting HRM-style practices through an integrated human resource information system An e-greenfield site?' Personnel Review, Vol. 30 No. 3, pp. 351-370.

'The Right Way to Reconstruct Iraq', 2005, The Globalist, May 26, viewed 26/9/2009

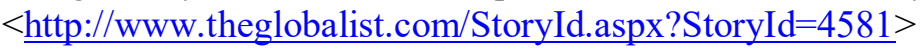


